\title{
Keanekaragaman Tumbuhan Paku Terestrial di Kawasan Hutan Pinus Gunung Pancar, Bogor
}

\author{
Anyelir Sukma Yolla ${ }^{1 *}$, Fitri Damayanti ${ }^{2}$, Efri Gresinta ${ }^{1}$ \\ ${ }^{I}$ Fakultas MIPA, Prodi Pendidikan Biologi, Universitas Indraprasta PGRI \\ ${ }^{2}$ Fakultas Pascasarjana, Prodi Pendidikan MIPA,Universitas Indraprasta PGRI \\ *email: ayelirsukmayolla@gmail.com
}

\begin{tabular}{l} 
Article History \\
\hline Received: \\
14/01/2022 \\
Revised: \\
21/01/2022 \\
Accepted: \\
26/01/2022 \\
\\
Kata kunci: \\
Keanekaragaman \\
Tumbuhan paku \\
terrestrial \\
Hutan pinus
\end{tabular}

Key word:

Diversity

Terrestrial ferns

Pine forests

\begin{abstract}
ABSTRAK
Tujuan dari penelitian ini adalah untuk mengetahui keanekaragaman tumbuhan paku terestrial di area camping ground A di kawasan hutan pinus Gunung Pancar, Bogor. Penelitian dilakukan menggunakan metode deskriptif. Penelitian dilaksanakan dari bulan Maret-Agustus 2021. Sampel tumbuhan paku dilakukan secara purposive sampling sesuai dengan jenis dan jumlah tumbuhan paku yang terdapat pada area tertentu dengan membuat line transect sepanjang jalur $20 \mathrm{~m}$ yang dibuat menjadi empat daerah transek masing-masing berukuran $5 \times 5 \mathrm{~m}$. Pengamatan juga dilakukan terhadap kondisi lingkungan abiotik, meliputi: intensitas cahaya, suhu udara, suhu tanah, kelembaban lingkungan, dan $\mathrm{pH}$ tanah. Diperoleh sepuluh jenis tumbuhan paku terestrial, yaitu: Blechnum orientale, Selanginella wildenowii, Dicranopteris linearis, Lygodium cirnatum, Pleocnemia irregularis, Pteris vittata, Pityrogramma calamelanos, Adiantum lunulatum, Marsilea crenata, dan Christella parasitica. Secara keseluruhan daerah transek di Area Camping Ground A Kawasan Hutan Pinus Gunung Pancar Bogor memiliki indeks keanekaragaman yang melimpah sedang yaitu 1.851 dan indeks kemerataan spesies yang merata yaitu 0.334 .
\end{abstract}

ABSTRACT
This study aimed to determine the diversity of terrestrial ferns in the camping ground area A in
the pine forest area of Mount Pancar, Bogor. This research was conducted using a descriptive
method. The research was carried out from March-August 2021. Sampling of ferns was carried
out by purposive sampling in accordance with the composition of the species and number of
ferns in a certain area by making a line transect along a $20 \mathrm{~m}$ line which was made into four
transect areas each measuring $5 x 5 \mathrm{~m}$. Observations were also made on environmental
conditions which included: light intensity, air temperature, soil temperature, environmental
humidity, and soil pH. The results obtained ten species of terrestrial ferns, namely: Blechnum
orientale, Selanginella wildenowii, Dicranopteris linearis, Lygodium cirnatum, Pleocnemia
irregularis, Pteris vittata, Pityrogramma calamelanos, Adiantum lunulatum, Marsilea crenata,
and Christella parasitica. Overall, the transect area in the Camping Ground A Area of the Pinus
Forest of Gunung Pancar Bogor has been a moderately abundant diversity index of 1.851 and a
species evenness index of 0.334 .

Copyright $\odot 2022$ LPPM Universitas Indraprasta PGRI. All Right Reserved

\section{PENDAHULUAN}

Indonesia memiliki keanekaragaman hayati baik flora maupun fauna tertinggi di dunia. Keanekaragaman jenis flora di Indonesia terbagi menjadi dua golongan besar yaitu tumbuhan berspora dengan jumlah 92251 jenis dan tumbuhan berbiji dengan jumlah 19232 jenis (Drajati $d k k$.,
2016). Di dunia terdapat 10000 spesies tumbuhan paku dan 3000 jenis diantaranya terdapat di Indonesia (Sandy $d k k$., 2016). Tumbuhan paku adalah salah satu divisi yang memiliki kormus, artinya tubuhnya dapat dibedakan antara bagian akar, batang ataupun daunnya (Tjitrosoepomo, 2011). Habitat tumbuhan paku adalah di daerahdaerah rawa, mangrove dan daerah pegunungan 
dengan kelembaban dan curah hujan yang tinggi (Katili, 2013).

Tumbuhan paku dapat bersifat epifit, higrofit, hidrofit, dan higrofit atau dapat pula hidup pada sisa-sisa tumbuhan lain (Wijana, 2014). Tumbuhan paku memiliki kelimpahan yang tinggi di hutan tropis terutama di hutan pegunungan (Amin \& Jumisah, 2019). Gunung Pancar dikelilingi oleh hutan pinus sehingga kawasan ini tergolong hutan tropis yang di dalamnya banyak ditemukan berbagai macam tumbuhan, salah satunya tumbuhan paku terestrial. Tumbuhan paku terrestrial berarti tumbuhan paku yang dapat hidup di tanah (beberapa jenis tanah dan batu kapur) (Hutasuhut \& Febriana, 2019).

Banyak penelitian yang telah membuktikan bila tumbuhan paku sangat bermanfaat. Tetapi keberadaanya kurang mendapat perhatian. Tumbuhan ini memiliki peranan penting baik di bidang kesehatan, lingkungan, dan ekologi. Tumbuhan paku di bidang kesehatan berperan sebagai anti bakteri (Dalli et al., 2007; Paul et al., 2011; Jarial et al., 2018), antioksidan (Chen et al., 2007; Jarial et al., 2018), anti tumor (Konoshima et al., 1996) bahkan sebagai anti kanker (Jarial et al., 2018; Tan et al., 2018). Peranan tumbuhan paku di bidang lingkungan sebagai bioindikator polusi udara dan hiperakumulator logam berbahaya (Francesconi et al., 2002; Tiwari et al., 2013; Iksan et al., 2019). Pada bidang ekologi, tumbuhan paku berperan sebagai penahan erosi (Chau \& Chu, 2018).

Keanekaragaman tumbuhan paku sampai saat ini masih kurang diperhatikan bila dibanding dengan kelompok tumbuhan lainnya. Tumbuhan paku merupakan kelompok tanaman yang jarang dieksplorasi dan didokumentasi (Bhattarai, 2017). Informasi mengenai keanekaragaman tumbuhan paku terestrial di Hutan Pinus Gunung Pancar Bogor masih sangat terbatas sehingga pengetahuan masyarakat mengenai manfaat dari melestarikan tumbuhan paku masih sangat kurang. Penelitian ini bertujuan mengkaji keragaman jenis tumbuhan paku terestrial di Kawasan Hutan Pinus Gunung Pancar, Bogor. Informasi keanekaragaman yang diperoleh diharapkan dapat menjadi sumber databest.

\section{METODE PENELITIAN}

Penelitian ini telah dilaksanakan dari bulan Maret-Agustus 2021. Lokasi penelitian dilakukan di area camping ground $A$ kawasan hutan pinus Gunung Pancar, Desa Karang Tengah, Kecamatan
Babakan Madang Kabupaten Bogor. Jenis penelitian ini adalah deskriptif kualitatif dengan subjeknya adalah tumbuhan paku terestrial. Lokasi penelitian ditentukan menggunakan Metode Purposive Sampling. Pada penelitian ini menggunakan metode line transek dengan panjang jalur $20 \mathrm{~m}$. Sepanjang jalur dibuat menjadi empat transek petak dengan masing-masing berukuran $5 \times 5 \mathrm{~m}$. Pengamatan dilakukan untuk memperoleh data identifikasi tumbuhan paku, parameter lingkungan, indeks keanekaragaman jenis (H'), dan Indeks kemerataan spesies (E').

\section{Identifikasi Tumbuhan Paku}

Jenis tumbuhan paku yang diperoleh dilakukan pengkoleksian spesimen. Setiap sampel tumbuhan yang dikoleksi diusahakan mengandung spora. Pengambilan sampel dilakukan pada pukul 07.0010.00 pagi. Pengawetan tumbuhan paku yang dikoleksi dilakukan dengan menggunakan alkohol $70 \%$, dilipat sedemian rupa di antara lipatan koran dan disimpan dalam kantong plastik bening. Setiap spesimen dari petak pengamatan diberi label gantung dan dicatat ciri-ciri morfologinya. Identifikasi dilakukan menggunakan beberapa buku acuan, yaitu: Jenis Paku Indonesia (Sastrapradja et al., 1979), Kerabat Paku (Sastrapadja \& Afrisiani, 1985), dan Comparative Morfology of Vaskular Plants (Foster \& Gifford, 1967).

\section{Parameter Lingkungan}

Parameter lingkungan yang diamati adalah faktor abiotik, yaitu: intensitas cahaya, suhu udara, kelembaban udara, $\mathrm{pH}$ tanah, dan suhu tanah.

a. Intensitas cahaya diukur menggunakan alat yaitu lux meter. Pengukuran intensitas cahaya dilakukan dengan mengarahkan sensor pada sumber cahaya selama 3 menit.

b. Pengukuran suhu udara dilakukan menggunakan air thermometer. Hasil pengukuran dinyatakan dalam ${ }^{\circ} \mathrm{C}$. Alat ini digunakan dengan cara menggenggam tali pada air thermometer dan diarahkan ke sumber udara selama kurang lebih 3 menit.

c. Data kelembaban udara diperoleh menggunakan alat hygrometer.

d. Pengukuran tingkat keasaman tanah dilakukan dengan soil $p H$. Pengukuran dilakukan dengan cara menancapkan soil $p H$ ke dalam lubang yang sudah disediakan dengan kedalaman 80$100 \mathrm{~cm}$. Pengambilan data dilakukan setelah sensor didiamkan selama kurang lebih 3 menit. 
e. Pengukuran suhu tanah dilakukan menggunakan alat yaitu soil thermometer. Hasil pengukuran dinyatakan dalam ${ }^{\circ} \mathrm{C}$. Alat ini digunakan dengan cara menancapkan pada lubang yang tidak terlalu dalam, kemudian ditutup dengan tanah hingga sensor tertutup. Data diambil setelah sensor didiamkan selama 3 menit.

Data yang diperoleh dari masing-masing parameter lingkungan abiotik adalah data rata-rata dari 3 kali pengukuran.

\section{Indeks Keanekaragaman Jenis (H')}

Indeks keanekaragaman jenis (H') ditentukan berdasarkan rumus Shannon Wiener (Brower \& Ende, 1997)

$\mathrm{H}^{\prime}=p i \operatorname{1n} p i$

Keterangan:

$\mathrm{Pi} \quad: \mathrm{ni} / \mathrm{N}$

H' : Indeks keanekaragaman jenis

$\mathrm{Ni} \quad$ : Jumlah individu jenis $i$

$\mathrm{N}$ : Jumlah total individu

Kemudian ditentukan tingkat keanekaragaman jenisnya yang dikelompokkan dalam tiga kategori yaitu:

$\begin{array}{ll}\mathrm{H}^{\prime}>3,5 & \text { : tinggi } \\ 1 \leq \mathrm{H}^{\prime} \leq 3 & \text { : sedang } \\ \mathrm{H}^{\prime}<1 & \text { : rendah }\end{array}$

\section{Indeks Kemerataan Spesies (E')}

Indeks kemerataan spesies ditentukan dengan rumus:

$\mathbf{E}^{\prime}=\mathbf{H}^{\prime} / \ln \mathrm{S}$

Keterangan:

$\mathrm{H}^{\prime} \quad$ : Indeks keanekaragaman jenis
$\mathrm{S} \quad$ : Jumlah tiap spesies

E' : Indeks kemerataan spesies

\section{HASIL DAN PEMBAHASAN}

Berdasarkan hasil pengamatan dan identifikasi yang telah dilakukan pada seluruh daerah transek di Area Camping Ground A Kawasan Hutan Pinus Gunung Pancar Bogor ditemukan 10 jenis tumbuhan paku terestrial yang termasuk ke dalam delapan famili (Tabel 1). Sepuluh jenis tumbuhan paku terestrial yang ditemukan adalah Blechnum orientale, Selanginella wildenowii, Dicranopteris linearis, Lygodium cirnatum, Pleocnemia irregularis, Pteris vittata, Pityrogramma calamelanos, Adiantum lunulatum, Marsilea crenata, dan Christella parasitica. Keberadaan tumbuhan paku terestrial memiliki jumlah dan presentase yang berbeda-beda. Jumlah dan jenis tumbuhan paku terestrial yang berbeda di suatu daerah dipengaruhi keadaan habitat tempat tumbuhan. Hal ini terbukti dari hasil penelitian Rizky dkk. (2018), memperoleh tiga spesies tumbuhan paku terestrial di wilayah Hutan dengan Tujuan Khusus (KHDTK) Banten, yaitu: Selaginella plana, Lygodium salicifolium, dan Diplazium esculentum. Hutasurhut \& Febriani (2018), menemukan 20 jenis tumbuhan pakupakuan di Taman Wisata Alam Sicike-cike Kabupaten Dairi Sumatera Utara. Jenis tumbuhan paku-pakuan yang mendominasi di wilayah tersebut adalah: Gleichenia linearis Burm, Hymenophyllum productum Kunze, dan Selliquea lima (V.A.V.R) Holtt.

Tabel 1. Spesies tumbuhan paku terestrial pada seluruh daerah transek

\begin{tabular}{|c|c|c|c|c|c|c|}
\hline \multirow{2}{*}{ No. } & \multirow{2}{*}{ Famili } & \multirow{2}{*}{ Spesies } & \multicolumn{4}{|c|}{ Jumlah individu pada tiap transek } \\
\hline & & & 1 & 2 & 3 & 4 \\
\hline 1. & Blechnaceae & Blechnum orientale & 12 & 10 & 11 & 9 \\
\hline 2. & Selanginellaceae & Selanginella wildenowii & 35 & 8 & 8 & 9 \\
\hline 3. & Gleicheniaceae & Dicranopteris linearis & 3 & 3 & 2 & 1 \\
\hline 4. & Lygodiaceae & Lygodium circinatum & 15 & 15 & 12 & 13 \\
\hline \multirow{2}{*}{5.} & \multirow{2}{*}{ Polypodiaceae } & Pleocnemia irregularis & 5 & 7 & 9 & 9 \\
\hline & & Pteris vittata & 2 & 2 & 11 & 4 \\
\hline \multirow{2}{*}{6.} & \multirow{2}{*}{ Pteridaceae } & Pityrogramma calamelanos & - & - & - & 1 \\
\hline & & Adiantum lunulatum & 3 & 1 & 1 & - \\
\hline 7. & Marsileaceae & Marcilea crenata & 1 & 2 & 1 & - \\
\hline 8. & Thelypteridaceae & Christella parasitica & 8 & 15 & 10 & 7 \\
\hline \multicolumn{3}{|c|}{ Total } & 84 & 63 & 66 & 53 \\
\hline
\end{tabular}

Tumbuhan paku yang ditemukan di lokasi penelitian berjumlah 10 jenis. Penampakan visual dari 10 jenis tumbuhan paku dapat dilihat pada
Gambar 1. Deskripsi dari masing-masing jenis paku tersebut adalah: 


\section{Blechnum orientale}

Klasifikasi ilmiah dari paku Blechnum orientale adalah:

$\begin{array}{ll}\text { Kingdom } & \text { : Plantae } \\ \text { Divisi } & : \text { Pteridophyta } \\ \text { Kelas } & \text { : Pteridopsida } \\ \text { Ordo } & \text { : Polypodiales } \\ \text { Famili } & : \text { Blechnaceae } \\ \text { Genus } & : \text { Blechnum } \\ \text { Spesies } & : \text { Blechnum orientale }\end{array}$

Blechnum orientale merupakan tumbuhan paku dalam famili Blechnaceae yang umumnya dikenal dengan nama paku lipan, lencir atau paku lubang. Jenis ini memiliki tinggi antara 0.35-2.50 m, berakar rimpang yang tegak dan kuat, daunnya rapat dan terdapat sisik, tidak beruas, panjang tangkai $10-40 \mathrm{~cm}$, terdapat banyak sisik coklat yang panjang dan panjang pada pangkalnya. Pada tanaman muda dan tua menyirip, anak daun atau tajuk banyak, dan dibagian dari daun fertil pangkalnya membulat berbentuk jantung, sangat rapat. Jenis ini ditemukan di daerah lereng dan tebing tanah.

\section{Selanginella wildenowii}

Klasifikasi ilmiah dari paku Selanginella wildenowii adalah:

$\begin{array}{ll}\text { Kingdom } & : \text { Plantae } \\ \text { Divisi } & : \text { Lycopodiophyta } \\ \text { Kelas } & : \text { Lycopodiopsida } \\ \text { Ordo } & : \text { Selanginellales } \\ \text { Famili } & : \text { Selanginellaceae } \\ \text { Genus } & : \text { Selanginella } \\ \text { Spesies } & : \text { Selanginella wildenowii }\end{array}$

Jenis ini memiliki rimpang yang menjalar panjang, daun mikrofil, memiliki percabangan daun berseling, berbentuk ujung daun seperti duri, warna daun hijau, di bawah naungan berwarna agak kebiruan. Tangkai bulat ditutupi oleh mikrofil. Tidak ditemukan daun fertil. Habitat terestrial terdapat pada yang tanah datar, miring, dan terdapat juga pada celah akar.

\section{Dicranopteris linearis}

Klasifikasi ilmiah dari paku Dicranopteris linearis adalah:

$\begin{array}{ll}\text { Kingdom } & \text { : Plantae } \\ \text { Divisi } & \text { : Pteridophyta } \\ \text { Kelas } & \text { : Gleicheniopsida } \\ \text { Ordo } & \text { : Gleicheniales } \\ \text { Famili } & \text { : Gleicheniaceae } \\ \text { Genus } & \text { : Dicranopteris } \\ \text { Spesies } & \text { : Dicranopteris linearis }\end{array}$

Jenis tumbuhan paku ini disebut juga pakis resam. Jenis ini memiliki percabangan yang khusus sehingga mudah dibedakan dengan jenis lain. Tiap cabangnya bercabang dua dan masing-masing cabang tersebut akan bercabang dua secara terusmenerus sehingga seluruh tumbuhan tertutupi tanah pada tempat tumbuhnya. Hal ini yang menyebabkan tumbuhan paku jenis ini mendominasi suatu daerah tanpa ada jenis lain.

\section{Lygodium circinatum}

Klasifikasi ilmiah dari paku Lygodium circinatum adalah:

$\begin{array}{ll}\text { Kingdom } & \text { : Plantae } \\ \text { Divisi } & : \text { Pteridophyta } \\ \text { Kelas } & \text { : Pteridopsida } \\ \text { Ordo } & : \text { Schizaeales } \\ \text { Famili } & \text { : Lygodiaceae } \\ \text { Genus } & : \text { Lygodium } \\ \text { Spesies } & \text { : Lygodium circinatum }\end{array}$

Paku ini disebut juga sebagai paku hatta dengan ciri rhizoma menjalar di bawah permukaan tanah. Jenis ini memiliki rachis atau tulang belakang memanjat, rachis steril dengan percabangan yang dikotom, berwarna hijau kecoklatan. Rachis primer memiliki panjang $24 \mathrm{~cm}$, rachis sekunder panjangnya mencapai $6.5 \mathrm{~cm}$. Rachis fertile memiliki percabangan dikotom, berwarna hijau kecoklatan.

\section{Pleocnemia irregularis}

Klasifikasi ilmiah dari paku Pleocnemia irregularis adalah:

Kingdom : Plantae

Divisi : Pteridophyta

Kelas : Filicinae

Ordo : Polypodiales

Famili : Polypodiaceae

Genus : Pleocnemia

Spesies : Pleocnemia irregularis

Jenis ini memiliki rimpal tegak bersisik coklat kehitaman, beberapa daun pada ujung ental menyatu, pangkal daun lebih lebar, anak daun paling bawah dekat tangkai memanjang ke bawah seperti pita, susunan daun berseling, jarak antar daun pendek, venasi menjalar, tepi bercelah, tangkai bersisik coklat, daun fertil tidak ditemukan. Habitat terestrial pada tebing selokan, tanah datar, dan tanah miring.

\section{Pteris vittata $\mathrm{L}$.}

Klasifikasi ilmiah dari paku Pteris vittata adalah:

Kingdom : Plantae 


$\begin{array}{ll}\text { Divisi } & : \text { Pteridophyta } \\ \text { Kelas } & : \text { Pteridopsida } \\ \text { Ordo } & : \text { Polypodiales } \\ \text { Famili } & : \text { Polypodiaceae } \\ \text { Genus } & : \text { Pteris } \\ \text { Spesies } & : \text { Pteris } \text { vittata } \text { L. }\end{array}$

$P$. vittata adalah jenis paku-pakuan yang hidup di tanah, tembok, atau di tebing yang terjal. Umumnya jenis paku ini menyukai kelembapan tinggi. Jenis ini memiliki rimpang yang menjalar pada permukaan batuan dengan perakaran yang masuk ke celah-celah batu. Akar P. vittata letaknya di bagian pangkal rimpang, tegak, tipis, kasar, dan berwarna coklat tua. Permukaan bawah daunnya terdapat sori (bentuk tunggal dari sorus), sorus berbentuk seperti garis pada tepi daun bagian bawah, susunan daun berhadapan atau bersilangan, Ujung daun berbentuk runcing dengan pangkal membentuk lobus. Daun paling bawah ukurannya pendek, semakin ke atas ukuran daun semakin panjang. Daun memiliki pertulangan menggarpu. Tangkai berwarna hijau dengan rambut putih.

\section{Pityrogramma calomelanos}

Klasifikasi ilmiah dari paku Pityrogramma calomelanos adalah:

$\begin{array}{ll}\text { Kingdom } & \text { : Plantae } \\ \text { Divisi } & \text { : Pteridophyta } \\ \text { Kelas } & \text { : Pteridopsida } \\ \text { Ordo } & : \text { Polypodiales } \\ \text { Famili } & \text { : Pteridaceae } \\ \text { Genus } & : \text { Pityrogramma } \\ \text { Spesies } & : \text { Pityrogramma calomelanos }(L) .\end{array}$

$P$. calomelanos disebut juga sebagai paku perak. Rimpang berbentuk tegak, bersisik coklat, tepi bercelah. Daun pada jenis ini adalah daun tunggal dengan warna hijau tua, bergerigi dengan ukuran lebar daun antara 1 sampai $2 \mathrm{~cm}$, ujung daunnya melancip, tulang daun menyirip, susunan daun berseling, venasi menggarpu, ental berwarna putih, tangkai daun berwarna hijau sampai kecoklatan hingga hitam mengkilat, batang berbentuk bulat silindris dengan ukuran sekitar 3 $\mathrm{cm}$, akar serabut. Habitat terestrial pada tanah miring, tanah datar dan tebing kali.

\section{Adiantum lunulatum}

Klasifikasi ilmiah dari paku Adiantum lunulatum adalah:

$\begin{array}{ll}\text { Kingdom } & \text { : Plantae } \\ \text { Divisi } & \text { : Pteridophyta } \\ \text { Kelas } & \text { : Pteridopsida } \\ \text { Ordo } & \text { : Polypodiales } \\ \text { Famili } & \text { : Pteridaceae }\end{array}$

Genus : Adiantum

Spesies : Adiantum lunulatum

Rimpang menjalar pendek atau tegak, bersisik kecil berwarna coklat, ental pinatus, susunan daun berseling berdekatan, daun berbentuk seperti kipas tipis, tepi bergelombang, pertulangan daun menggarpu menyentuh tepi, daun fertil berukuran lebih kecil dengan tepi berlekuk membentuk lobus, tangkai kecil hitam mengkilat bercelah dan berambut, sorus seperti garis yang tidak menyatu di tepi daun, berlekuk membentuk lobus, terdapat bulbil pada ujung ental sebagai alat perkembangbiakan vegetatif. Habitat terestrial pada tanah datar, tebing selokan atau kali, dan celah akar.

\section{Marsilea crenata}

Klasifikasi ilmiah dari paku Marsilea crenata adalah:

$\begin{array}{ll}\text { Kingdom } & \text { : Plantae } \\ \text { Divisi } & \text { : Pteridophyta } \\ \text { Kelas } & \text { : Pteridopsida } \\ \text { Ordo } & \text { : Salvinales } \\ \text { Famili } & \text { : Marsileaceae } \\ \text { Genus } & \text { : Marcilea } \\ \text { Spesies } & \text { : Marcilea crenata }\end{array}$

$M$. crenata yang biasa dikenal dengan nama semanggi. Semanggi merupakan kelompok paku air yang memiliki ciri khas yang menyerupai payung tersusun atas empat anak daun yang saling berhadapan. Habitat terestrial ditemukan di selokan, genangan air sedikit, dan tanah miring.

\section{Christella parasitica}

Klasifikasi ilmiah dari paku Christella parasitica adalah:

$\begin{array}{ll}\text { Kingdom } & \text { : Plantae } \\ \text { Divisi } & \text { : Pteridophyta } \\ \text { Kelas } & \text { : Pteridopsida } \\ \text { Ordo } & \text { : Polypodiales } \\ \text { Famili } & \text { : Thelypteridaceae } \\ \text { Genus } & : \text { Christella } \\ \text { Spesies } & : \text { Christella prasitica }\end{array}$

C. prasitica adalah jenis tumbuhan paku yang hidup ditanah terutama kawasan lembab, rimpang merambat panjang dan tegak, ental dipenuhi rambut berwarna putih, memiliki daun menyirip ganda dua, susunan daun berseling, ujung daun meruncing, tepi daun bergerigi, bersisik coklat, jarak antar daun sangat rapat, venasi menggarpu, terdapat rambut berwarna putih tipis, tangkai tegak berwarna hijau dengan sedikit rambut putih, bagian bawah tangkai bersisik coklat, sorus terletak pada abaksial daun, sorus tersusun dua-dua terletak 
dekat tulang daun. Habitat terestrial pada tanah datar dan tembok selokan.

\section{Parameter Lingkungan}

Daerah transek Area Camping Ground A Kawasan Hutan Pinus Gunung Pancar Bogor memiliki intensitas cahaya berkisar antara 2300 sampai 2805 lux dengan suhu udara $27-31^{\circ} \mathrm{C}$, kelembaban udara 80-84\%, pH tanah 6-6.8, dan suhu tanah $25-27^{\circ} \mathrm{C}$ (Tabel 2). Pertumbuhan dan perkembangan suatu tumbuhan dipengaruhi oleh faktor dalam atau internal, yaitu gen dan hormon dan faktor luar atau eksternal yaitu air, cahaya matahari, mineral, kelembaban, dan suhu (Saktyowati, 2010).

Daerah transek yang memiliki intensitas cahaya paling tinggi adalah daerah transek 1 dan 4 . Pada kedua daerah transek tersebut tidak terdapat tutupan tajuk dan naungan tetapi tumbuhan paku dapat hidup pada kondisi tersebut, salah satunya yaitu Selanginella wildenowii. Selanginella wildenowii memiliki warna daun agak kebiruan sebagai bentuk adaptasi dalam menyaring cahaya melalui kanopi hutan. Sedangkan daerah transek 2 dan 3 memiliki intensitas cahaya yang paling rendah namun kondisi tersebut menjadi habitat yang disukai oleh tumbuhan paku, seperti Lygodium cirnatum dan Christella parasitica yang banyak ditemukan pada daerah transek tersebut. Intensitas cahaya yang rendah dipengaruhi oleh tutupan tajuk dan awan, hal ini adalah kondisi yang cocok dengan habitat tumbuhan paku yang menyukai akan kelembaban (Lubis, 2009). Spesies Lygodium cirnatum dan Christella parasitica banyak ditemukan di daerah transek 2 karena kedua spesies tersebut sudah berada pada habitat yang sesuai.

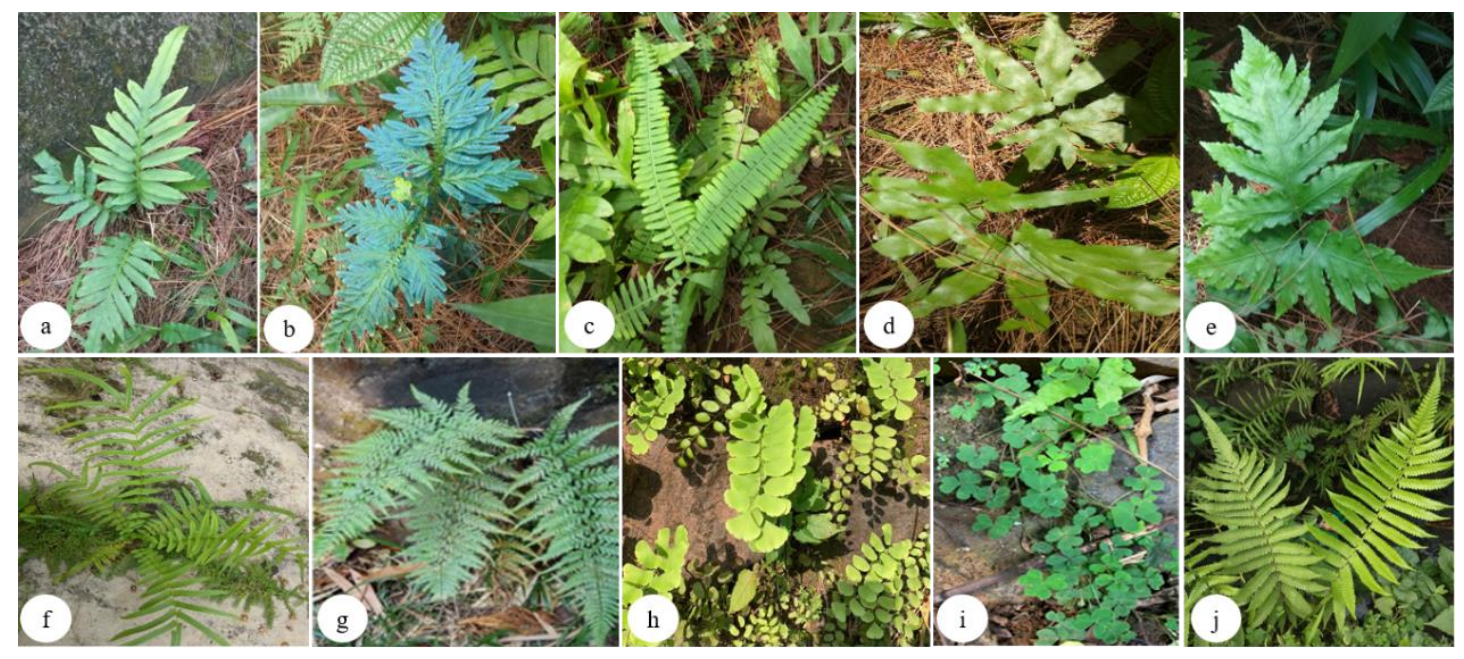

Gambar 1. Penampakan visual tumbuhan paku terestrial. a. Blechnum orientale; b. Selanginella wildenowii; c. Dicranopteris linearis; d. Lygodium circinatum; e. Pleocnemia irregularis; f. Pteris vittata L; g. Pityrogramma calomelanos; h. Adiantum lunulatum; i. Marsilea crenata; j. Christella parasitica

Kelembaban dipengaruhi oleh suhu udara. Kelembaban udara akan bertambah dengan menurunnya suhu (Lubis, 2009). Hal tersebut sesuai, karena pada daerah transek 2 dan 3 memiliki kelembaban tinggi namun suhu yang rendah sehingga mengakibatkan jumlah spesies yang ditemukan banyak dan beragam. Berbeda dengan daerah transek 1 dan 4 yang memiliki kelembaban rendah dan suhu yang tinggi sehingga mengakibatkan jumlah spesies yang ditemukan jumlahnya lebih sedikit.

Suhu tanah juga tidak kalah penting peranannya bagi pertumbuhan tumbuhan paku. Suhu tanah pada daerah transek 1 adalah $27^{\circ} \mathrm{C}$, pada daerah transek 2 suhu tanahnya $25^{\circ} \mathrm{C}$, pada daerah transek 3 suhu tanahnya $25.7^{\circ} \mathrm{C}$. dan pada daerah transek 4 suhu tanahnya $26^{\circ} \mathrm{C}$. Suhu tanah optimum di daerah tropis untuk tumbuhan paku berkisar antara 21-27 ${ }^{\circ} \mathrm{C}$ (Nawawi et al., 2014). Pada seluruh daerah transek memiliki rata-rata suhu tanah yaitu $25.92^{\circ} \mathrm{C}$. Hal ini membuktikan bahwa suhu tanah pada seluruh daerah transek termasuk kedalam suhu tanah optimum untuk pertumbuhan tumbuhan paku sehingga tumbuhan paku dapat tumbuh dengan baik. 
Tabel 2. Parameter lingkungan pada seluruh daerah transek

\begin{tabular}{ccccccc}
\hline \multirow{2}{*}{ No. } & Lokasi & $\begin{array}{c}\text { Intensitas Cahaya } \\
(\mathbf{l u x})\end{array}$ & $\begin{array}{c}\text { Suhu Udara } \\
\left({ }^{\circ} \mathbf{C}\right)\end{array}$ & $\begin{array}{c}\text { Kelembaban } \\
\text { Udara }(\%)\end{array}$ & $\begin{array}{c}\text { pH } \\
\text { Tanah }\end{array}$ & $\begin{array}{c}\text { Suhu Tanah } \\
\left({ }^{\circ} \mathbf{C}\right)\end{array}$ \\
\hline 1. & Transek 1 & 2610 & 31 & 81 & 6 & 27 \\
2. & Transek 2 & 2330 & 28 & 84 & 6.6 & 25 \\
3. & Transek 3 & 2435 & 27 & 83 & 6.8 & 25.7 \\
4. & Transek 4 & 2805 & 29 & 80 & 6.3 & 26 \\
\hline
\end{tabular}

\section{Indeks Keanekaragaman (H')}

Hasil nilai indeks keanekaragaman spesies memperlihatkan pada daerah transek 3 memiliki nilai indeks keanekaraman yang lebih tinggi bila dibandingkan daerah transek lainnya (Tabel 3). Hal ini berkaitan dengan kesesuaian suhu dan kelembaban pada daerah transek 3 yang sesuai dengan kondisi yang disukai tumbuhan paku untuk hidup sehingga banyak jenis tumbuhan paku yang terdapat di kedua daerah transek tersebut. Menurut Wirakusumah (2003), tingginya nilai keanekaragaman pada wilayah tertentu mengindikasikan kestabilan komunitas di wilayah tersebut. Secara keseluruhan rata-rata nilai indeks keanekaragaman pada seluruh daerah transek adalah 1.851. Hal ini menunjukkan bahwa $1 \leq \mathrm{H}^{\prime} \leq$
3, maka keanekaragaman tumbuhan paku terestrial pada seluruh daerah transek di Area Camping Ground A Kawasan Hutan Pinus Gunung Pancar Bogor tergolong melimpah sedang karena tumbuhan paku terestrial yang ditemukan masih banyak dan relatif stabil dan merata. Komunitas memiliki keanekaragaman spesies yang tinggi bila banyaknya spesies merata (Zulkarnain, 2004). Indeks keanekaragaman sedang berarti rasio antara jumlah individu suatu jenis terhadap jumlah total individu seluruh jenis bernilai sedang (Ceri et al., 2014). Jumlah spesies semakin banyak maka keanekaragamannya akan semakin tinggi (Purnawati et al., 2014). Tetapi sebaliknya, jika sedikit jumlah spesiesnya maka rendah keanekaragamannya (Ridianingsih et al., 2017).

Tabel 3. Hasil indeks keanekaragaman tumbuhan paku terestrial

\begin{tabular}{|c|c|c|c|c|c|}
\hline \multirow{2}{*}{ No. } & \multirow{2}{*}{ Spesies } & \multicolumn{4}{|c|}{ H' } \\
\hline & & Transek 1 & Transek 2 & Transek 3 & Transek 4 \\
\hline 1. & Blechnum orientale & 0.277 & 0.291 & 0.300 & 0.300 \\
\hline 2. & Selanginella wildenowii & 0.364 & 0.260 & 0.257 & 0.300 \\
\hline 3. & Dicranopteris linearis & 0.117 & 0.143 & 0.105 & 0.072 \\
\hline 4. & Lygodium circinatum & 0.307 & 0.341 & 0.311 & 0.344 \\
\hline 5. & Pleocnemia irregularis & 0.166 & 0.243 & 0.273 & 0.300 \\
\hline 6. & Pteris vittata & 0.086 & 0.107 & 0.300 & 0.194 \\
\hline 7. & Pityrogramma calamelanos & - & - & - & 0.072 \\
\hline 8. & Adiantum lunulatum & 0.117 & 0.062 & 0.062 & - \\
\hline 9. & Marsilea crenata & 0.049 & 0.107 & 0.062 & - \\
\hline 10. & Christella parasitica & 0.223 & 0.341 & 0.287 & 0.267 \\
\hline & Total & 1.706 & 1.895 & 1.957 & 1.849 \\
\hline
\end{tabular}

\section{Indeks Kemerataan (E')}

Tabel 4 memperlihatkan nilai indeks kemerataan jenis pada masing-masing transek. Daerah transek 1 memiliki nilai indeks kemerataan jenis 0.283 , daerah transek 2 bernilai 0.354 , daerah transek 3 bernilai 0.345 , dan daerah transek 4 bernilai 0.355 . Secara keseluruhan rata-rata nilai indeks kemerataan pada seluruh daerah transek memiliki nilai yang mendekati angka satu yaitu 0.334. Hal ini menunjukkan bahwa kemerataan jenisnya semakin tersebar relatif merata pada komunits tersebut. 
Tabel 4. Hasil indeks kemerataan tumbuhan paku terestrial

\begin{tabular}{cccccc}
\hline \multirow{2}{*}{ No. } & \multirow{2}{*}{ Spesies } & \multicolumn{3}{c}{ E' } \\
\cline { 2 - 6 } & Transek 1 & Transek 2 & Transek 3 & Transek 4 \\
\hline 1. & Blechnum orientale & 0.023 & 0.029 & 0.027 & 0.033 \\
2. & Selanginella wildenowii & 0.010 & 0.032 & 0.032 & 0.033 \\
3. & Dicranopteris linearis & 0.039 & 0.047 & 0.052 & 0.072 \\
4. & Lygodium circinatum & 0.020 & 0.022 & 0.025 & 0.026 \\
5. & Pleocnemia irregularis & 0.033 & 0.034 & 0.030 & 0.033 \\
6. & Pteris vittata & 0.043 & 0.053 & 0.027 & 0.048 \\
7. & Pityrogramma calamelanos & - & - & - & 0.072 \\
8. & Adiantum lunulatum & 0.039 & 0.062 & 0.062 & - \\
9. & Marsilea crenata & 0.049 & 0.053 & 0.062 & - \\
10. & Christella parasitica & 0.027 & 0.022 & 0.028 & 0.038 \\
\hline \multicolumn{7}{r}{} & Total & 0.283 & 0.354 & 0.345 & 0.355 \\
\hline
\end{tabular}

\section{KESIMPULAN}

Terdapat sepuluh jenis tumbuhan paku terrestrial di Area Camping Ground A Kawasan Hutan Pinus Gunung Pancar Bogor, yaitu Blechnum orientale, Selanginella wildenowii, Dicranopteris linearis, Lygodium cirnatum, Pleocnemia irregularis, Pteris vittata, Pityrogramma calamelanos, Adiantum lunulatum, Marsilea crenata, dan Christella parasitica. Secara keseluruhan daerah pengamatan memiliki indeks keanekaragaman tergolong melimpah sedang yaitu 1.851 dengan indeks kemerataan spesies yang merata sebesar 0.334 .

\section{DAFTAR PUSTAKA}

Amin, N., \& Jumisah. (2019). Jenis tumbuhan paku di Kawasan Terutung Kute Kecamatan Darul Hasanah Kecamatan Aceh Tenggara. Biotik, 7(1),

18-27. http://dx.doi.org/10.22373/biotik.v7i1.5466.

Bhattarai, S., \& Rajbandhary, S. (2017). Flora Pteridophyte di Kawasan Konservasi Manaslu Nepal Tengah. International Journal of Geomate, 8(1), 680-687.

Brower, Z., \& Ende, V. (1997). Field and Laboratory Methods for General Ecology. WCB. McGraw Hill: Boston.

Ceri, B., Lovadi, I., \& Linda, R. (2014). Keanekaragaman jenis paku-pakuan (Pteridophyta) di Mangrove Muara Sungai Peniti Kecamatan Segedong Kabupaten Pontianak. Protoboint, 3(2), 240-246. http://dx.doi.org/10.26418/protobiont.v3i2.682 6.

Chau, N. L., \& Chu, L. M. (2018). Fern cover and the importance of plant traits in reducing erosion on steep soil slopes. Catena, 151, 98106.

Chen, Y. H., Chang, C, R., Lin, Y. L., Wang, L., Chen, J. F., \& Wu, M. J. (2007). Identification of phenolic antioxidants from sword brake fern (Pteris ensiformis). Burm. J. Food Chem, 105, 48-59.

https://doi.org/10.1016/j.foodchem.2007.03.05 5.

Dalli, A. K., Saha, G., \& Chakraborty, U. (2007). Characterization of antimicrobial compound from a common fern Pteris bearutica. Indian $J$. Exp. Biol, 45, 285-290.

Drajati, W., Pratiwi, S., Herwinda, E., Radiansyah, A. D., Nalang, V. S., Nooryanto, B., Raharjoe, J. S., Ubaidillah, R., Maryanto, I., Kurniawan, R., Prasetyo, T. A., Rahim, A., Jefferson, J., \& Hakim, F. (2016). Indonesia Biodiversity Strategy and Action Plan 2015-2020. Bappenas: Jakarta.

Foster, A. S., \& Gifford, Jr, E. M. (1967). Comparative Morphology of Vascular Plants. Second Indian Edition. pp. 31-35. Vaklis Feffer and Simons Private Ltd: Bombay.

Francesconi, K., Visootiviseth, P., Sridokchan, V., \& Goessler, W. (2002). Arsenicspecies in an arsenic hyperaccumating fern, pityrogramma calomenalos: A Potential Phytoremediator of Arsenic-contaminated soils. Sci.Total Environ, 284, 27-35. http://doi.org/ 10.1016/s00489697(01)00854-3.

Rizky, H., Primasari, R., Kurniasih, Y., \& Vivanti, D. (2018). Keanekaragaman jenis tumbuhan paku terestrial di Kawasan Hutan dengan Tujuan Khusus (KHDTK) Banten. Biosfer, $3(1), 6-12$.

Hutasuhut, M. A., \& Febriani, H. (2019). Keanekaragaman paku-pakuan terestrial di Kawasan Taman Wisata Alam Sicike-Cike. 
Biolokus, 2(1),

146-157. http://dx.doi.org/10.30821/biolokus.v2i1.441.

Iksan, M., La Aba, \& Kusrin. (2019). The ability of ferns to accumulate heavy metals $(\mathrm{Hg}, \mathrm{Pb}$ and $\mathrm{Cd})$ in the waters of the Gorontalo River. International Journal of Applied Biology, 3(1), 36-44.

https://doi.org/10.20956/ijab.v3i1.5930.

Jarial, R., Shard, A., Thakur, S., Sakinah, M., Zularisam, A. W., Rezania, S., Kanwar, S. S., \& Singh, L. (2018). Science characterization of flavonoids from fern Cheilanthes tenuifolia and evaluation of antioxidant, antimicrobial and anticancer activities. Journal of King Saud Science, 30(4), 425-432. https://doi.org/10.1016/j.jksus.2017.04.007.

Katili. (2013). Deskripsi pola penyebaran dan faktor bioekologis tumbuhan paku (Pteridophyta) di Kawasan Cagar Alam Gunung Ambang Kabupaten Bolaang Mongondow Timur. Saintek, 7(1), 35-41.

Konoshima, T., Takashi, M., Tokeda, H., Masuda, K., Arai, Y., Shiojima, K., \& Ageta, H. (1996). Anti-tumor promoting activities of triterpenoid from ferns. Biological \& Pharmmaceutical Bulletin, 19, 962-965.

Lubis, S. R. (2009). Keanekaragaman dan Pola Distribusi Tumbuhan Paku di Hutan Wisata Alam Eden Kabupaten Toba Samosir Provinsi Sumatra Utara. Tesis. Universitas Sumatra Utara.

Nawawi, G. R., Indriyanto., \& Duryat. (2014). Identifikasi jenis epifit dan tumbuhan yang menjadi penopangnya di blok perlindungan dalam Kawasan Hutan Raya Wan Abdul Rachman. Jurnal Sylva Lestari, 2(3), 3948. http://dx.doi.org/10.23960/js13239-48.

Paul, R. K., Irudayaraj, V., Johnson, M., \& Patric, R. D. (2011). Phytochemical and anti-bacterial activity of epidermal glands extract of Christella parasitica (L) H. Lev. Asian Pac. J. Trop. Biomed, 1, 8-11. http://doi.org/10.1016/S2221-1691(11)600592.

Purnawati, U., Turnip, M., \& Lovadi, I. (2014) Eksplorasi paku-pakuan (Pteridophyta) di Cagar Alam Mandor Kabupaten Landak.
Ptotoboint, 3(2), 155165. http://dx.doi.org/10.26418/protobiont.v3i 2.5525 .

Ridianingsih, D. S., Pujiastuti., \& Hariani, S. A. (2017). Inventarisasi tumbuhan paku (Pteridophyta) di Pos Rowobendo Ngagelan Taman Nasional Alas Purwo Kabupaten Banyuwangi. Bioeskperimen, 3(2), 20-30. https://doi.org/10.23917/bioeksperimen.v3i2.5 179.

Sakyowati, D. (2010). Mengenal Dunia Tumbuhan. Multazam Mulia Utama: Jakarta.

Sandy., Pantiwati., Hutha., \& Latifa. (2016). Keanekaragaman Jenis Tumbuhan Paku (Pteridophyta) di Kawasan Air Terjun Lawean Sendang Kabupaten Tulungagung. Prosiding Seminar Nasional, 2(6), 23-31.

Sastrapradja, S., Afriantini, J. J., Daenaedi, D., \& Widjaja, E. A. (1979). Jenis Paku Indonesia. Jakarta. LIPI: Jakarta.

Sastrapradja, S., \& Afriastini, J. J. (1980). Kerabat Paku. Lembaga Biologi Nasional: Jakarta.

Tjitsoepomo, G. (2011). Taksonomi Tumbuhan (Scizophyta, Thallophyta Bryophyta, Pteridophyta). Gadjah Mada University Press: Yogyakarta.

Tan, S. T., Ong, H. C., Chai, T. T., \& Wong, F. C. (2018). Identification of Potential Anticancer Protein Targets in Cytotoxicity Mediated by Tropical Medicinal Fern Extracts, 227-230. https://doi.org/10.4103/pm.pm.

Tiwari, S., Sarangi, B. K., Anusha, P., \& Pandey, R. A. (2013). Recent Advances Towards Improved Phytoremediation of Heavy Metal Pollution. In: Metal Hyperaccumulating Ferns: Progress and Future Prospects. David W.M. Leung (Ed). Bentham Science Publishers: Sharja.

Wijana, N. (2014). Biologi dan Lingkungan. Plantaxia: Yogyakarta.

Wirakusumah, S. (2003). Dasar-dasar Ekologi bagi Populasi dan Komunitas. UI Press: Jakarta.

Zulkarnain. 2004. Identifikasi Keanekaragaman Pteridophyta di Daerah Sukamade Taman Nasional Maeru Betiri Kabupaten Banyuwangi. Skripsi. Universitas Muhammadiyah Malang.

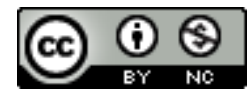

This work is licensed under a Creative Commons Attribution-NonCommercial 4.0 International License 